\title{
ADOPSI INOVASI BUDIDAYA KAMBING PERANAKAN ETAWA (PE) DI KABUPATEN KULON PROGO PROVINSI D.I. YOGYAKARTA
}

\author{
Puspo Sasmito \\ Program Studi Ilmu Komunikasi \\ Program Pascasarjana Universitas Sebelas Maret Surakarta \\ email: pusposas1979@gmail.com
}

\begin{abstract}
ABSTRAK
Tujuh puluh lima desa di Kabupaten Kulon Progo Provinsi D.I Yogyakarta termasuk kategori pedesaan, dimana 22 desa diantaranya berada pada lereng/punggung bukit. Ketiadaan lahan sawah pada wilayah desa yang terletak pada lereng bukit ini, membuat masyarakat hanya mengandalkan sektor perkebunan sebagai tumpuan pendapatan. Kakao dan cengkeh merupakan 2 (dua) komoditi utama yang banyak dibudidayakan masyarakat meskipun kedua komoditi ini memerlukan waktu yang relatif lama untuk bisa diperoleh hasilnya sehingga dapat belum mampu memenuhi kebutuhan mereka sehari-hari, sehingga memaksa mereka baik itu sendiri maupun berkelompok berusaha mencari peluang usaha-usaha lain yang diharapkan dapat memenuhi kebutuhan hidup mereka. Kelompok tani Mantep Makaryo di Kecamatan Kokap dan Mendasari di Kecamatan Samigaluh adalah sedikit contoh dari upaya masyarakat untuk melakukan usaha mendapatkan perbaikan pendapatan melalui budidaya kambing peranakan etawa (PE). Penelitian ini bertujuan untuk mengetahui bagaimana proses difusi inovasi yang terjadi pada masing-masing kelompok ternak, dimana kedua kelompok ini mempunyai perbedaan karakteristik yang mendasar, tetapi secara bergantian mampu meraih penghargaan tingkat nasional pada tahun 2014 dan 2015. Kelompok ternak Mendasari secara swadaya mengadopsi budidaya kambing PE dan menjadi penopang perekonomian anggota kelompoknya sementara kelompok ternak Mantep Makaryo merupakan kelompok binaan Fakultas Kedokteran Hewan UGM Yogyakarta berusaha mengembangkan usaha agribisnis dari pembibitan, produksi pupuk hingga pengolahan susu. Proses adopsi inovasi: knowledge, persuasion, decision, implementation dan confirmation sangat ditentukan oleh inisiatif dan keinovatifan, sehingga dukungan dari luar kelompok bukan menjadi faktor utama sebuah inovasi mampu secara cepat diadopsi dan menghasilkan perbaikan kehidupan serta peningkatan status sosial ekonomi masyarakat.
\end{abstract}

Kata kunci: adopsi inovasi, kambing etawa (PE)

\section{ABSTRACT}

Seventy five villages in Kulon Progo Yogyakarta Province D.I including rural category, where 22 villages of which are on a slope/ ridge. The absence of wetland in the area of the villages located on the hillside, makes people rely solely on the plantation sector as a pedestal revenue. Cocoa and clove are two (2) principal crops cultivated society although these commodities requires a relatively long time to be gained results that can not meet their needs in everyday life, thus forcing them either alone or in groups seek business opportunities others are expected to meet their life needs. Mantep Makaryo farmer groups in Kokap and Mendasari in District Samigaluh are few examples of community efforts to do business earn revenue improvements through the cultivation of hybrid goats etawa (PE). This study aims to determine how the process of diffusion of innovations that occur in each herd, where the two groups have different fundamental characteristics, but in turn is able to achieve national awards in 2014 and 2015. Underlying livestock group independently adopt goat farming PE and became the backbone of the economy of members of the group while the herd Mantep Makaryo a guided 
group of the Faculty of Veterinary Medicine UGM trying to develop agribusiness of seeding, fertilizer production to processing milk. The adoption process of innovation: knowledge, persuasion, decision, implementation and confirmation is largely determined by the initiative and keinovatifan, so support from outside groups is not a major factor in an innovation capable of rapidly adopted and resulted in improvement of life and the improvement of the socioeconomic status.

Keywords: adoption of innovation, goat hybrid etawa (PE)

\section{A. PENDAHULUAN}

Secara umum sektor pertanian masih menjadi tulang punggung ekonomi masyarakat Indonesia, meskipun beberapa dekade terakhir pemerintah telah berusaha mengarahkan agar pembangunan mengubah struktur ekonomi Indonesia yang berbasis pertanian menjadi perekonomian yang berbasis industri. Di Kabupaten Kulon Progo, dari 75 desa yang masuk kategori perdesaan, 22 desa diantaranya berada pada lereng/ punggung bukit, sehingga mereka hanya mengandalkan perkebunan dan peternakan sebagai sumber pendapatan utama (BPS, 2014). Kakao dan cengkeh merupakan 2 (dua) komoditi utama yang banyak dibudidayakan masyarakat. Kedua komoditi ini memerlukan waktu yang relatif lama untuk bisa diperoleh hasilnya, sehingga tingkat kehidupan masyarakat masih sangat jauh untuk dikatakan sejahtera karena sebagian besar masyarakat tidak mempunyai usaha lain yang mampu meningkatan penghasilan mereka sehari-hari.

Berbagai kesulitan yang dihadapi masyarakat yang tinggal di wilayah perbukitan Menoreh dalam mengusahakan lahan perkebunannya, menjadikan masyarakat melalui kelompok-kelompok tani, berusaha mencari usaha-usaha baru yang dapat mereka usahakan, dengan harapan mampu memberikan solusi atas permasalahan pendapatan keluarga yang selama ini mereka hadapi. Selain melakukan pengembangan usaha perkebunan yang mereka usahakan, beberapa kelompok juga melakukan perluasan usaha berupa peternakan dan agribisnis.

Kelompok tani Mantep Makaryo di Kecamatan Kokap dan kelompok peternak
Mendasari di desa Ngargosari Kecamatan Samigaluh Kabupaten Kulon Progo adalah sedikit contoh dari upaya masyarakat untuk melakukan diversifikasi usaha dari perkebunan yang selama ini mereka usahakan menjadi usaha peternakan kambing ras baru $\mathrm{PE}$, dengan harapan mampu meningkatkan pendapatan sehari-hari. Kambing peranakan etawa (PE) merupakan kambing ras baru hasil persilangan kambing Etawa dari India dengan kambing lokal yang pada awalnya dibudidayakan di Kecamatan Kaligesing, Kabupaten Purworejo, Jawa Tengah, yang berbatasan langsung dengan beberapa kecamatan di Kabupaten Kulon Progo.

\section{B. METODE PENELITIAN}

Penelitian ini merupakan penelitian deskriptif komparatif yang dimaksudkan untuk melakukan komparasi (perbandingan) antara 2 (dua) kelompok peternak. Survei analitik komparatif dilakukan untuk membuat komparasi (membandingkan) antara variabel yang satu dengan varabel lainnya yang sejenis (Kriyantono, 2006). Kedua kelompok peternak yang akan diteliti mempunyai bidang usaha yang sama, tetapi dari sisi inovasi mempunyai faktor pembeda yang dapat diperbandingkan, yaitu kelompok peternak Mendasari merupakan kelompok mandiri sejak didirikan, sementara kelompok Mantep Makaryo sejauh ini mendapatkan pendampingan dari Fakultas Kedokteran Hewan Universitas Gajah Mada Yogyakarta.

Analisis data dilakukan 2 (dua) tahap. Pertama, analisis deskriptif yang digunakan untuk melihat proses adopsi inovasi yang terjadi di dalam kedua kelompok. Kedua, analisis hubungan yang digunakan untuk melihat hubungan variabel mempengaruhi 
proses difusi inovasi. Analisis dilakukan dengan analisi regresi pada paket program SPSS 20.0.

\section{HASIL DAN PEMBAHASAN}

\section{Inovasi}

Bagi anggota kelompok ternak Mendasari dan Mantep Makaryo, budidaya kambing PE merupakan sebuah inovasi, meskipun pada kesempatan sebelumnya beberapa dari anggota kelompok sudah membudidayakan kambing jenis lain. Rogers (1981) menyatakan, baru dalam ide yang inovatif tidak berarti harus baru sama sekali, kebaruan inovasi ini diukur secara subyektif menurut pandangan individu yang menangkapnya. Hal ini karena inovasi adalah suatu gagasan, tindakan atau benda yang dianggap baru oleh seseorang atau sekelompok orang mereka telah mengusahakan.

Rogers (1983) mengemukakan lima karakteristik inovasi antara lain relative advantage, compatibility, complexity, triability dan observability. Budidaya kambing PE memiliki nilai relative advantage, karena dianggap lebih unggul daripada ternak kambing yang selama ini diusahakan.

Tabel 1. Persepsi Peternak Terhadap Inovasi Budidaya Kambing PE

\begin{tabular}{lccc}
\hline $\begin{array}{c}\text { Persepsi } \\
\text { terhadap inovasi }\end{array}$ & $\begin{array}{c}\text { Menda } \\
\text { sari }\end{array}$ & $\begin{array}{c}\text { Mantep } \\
\text { Makaryo }\end{array}$ & Total \\
\hline \multicolumn{1}{c}{$(1)$} & $(2)$ & $(3)$ & $(4)$ \\
\hline Tingkat kesulitan & & & \\
Sangat Mudah & 12.0 & 28.6 & 19.6 \\
Mudah & 84.0 & 61.9 & 73.9 \\
Sulit & 4.0 & 9.5 & 6.5 \\
\hline Cara memelihara kambing & & \\
Sangat tahu & 20.0 & 14.3 & 17.4 \\
Tahu & 76.0 & 81.0 & 78.3 \\
Kurang tahu & 4.0 & 4.8 & 4.3 \\
\hline Alasan memelihara PE & & \\
Harga jual tinggi & 84.0 & 76.2 & 80.4 \\
Mudah dipelihara & 0.0 & 9.5 & 4.3 \\
Sesuai Iklim & 0.0 & 9.5 & 4.3 \\
Lainnya: hobi,dll & 16.0 & 4.8 & 10.9 \\
\hline
\end{tabular}

sumber : hasil survey, diolah
Sebagian besar anggota kelompok menyatakan bahwa mereka mau mengadopsi budidaya kambing PE karena tergiur harga jual yang tinggi $(80,4 \%)$, sementara yang menyatakan sebagai hobi $(10,9 \%)$ dan $(8,6$ $\%)$ karena sesuai iklim dan mudah dipelihara.

Budidaya kambing PE memenuhi karakteristik compatibility, hal ini dapat dilihat dari pengalaman anggota kelompok sebelum membudidayakan kambing $P E$, beberapa diantaranya sudah mengusahakan kambing dan beberapa ternak kecil lainnya, sehingga sebagian besar tidak merasa kesulitan untuk beralih membudidayakan kambing PE. Tentang cara memelihara kambing 95,7 \% responden menyatakan tahu dan sangat tahu cara memelihara kambing, sehingga mereka tidak kesulitan ketika harus beralih kepada budidaya kambing PE

Dalam hal complexity, hanya (6,5\%) dari responden yang menyatakan budidaya kambing PE sulit, sementara (19,6\%) mengatakan sangat mudah dan (73,9\%) mengatakan mudah. Sementara untuk dua karakteristik terakhir yaitu triability dan observability, sebelum inovasi ini diadopsi, para peternak dapat melihat dan belajar langsung melalui ketua kelompok dan beberapa orang yang sebelum bergabung dengan kelompok sudah membudidayakan kambing PE.

\section{Adopsi Inovasi}

\section{Pengambilan keputusan dalam proses adopsi inovasi}

Rogers (1983) menyatakan proses keputusan adopsi inovasi dimulai seseorang atau pengambil keputusan mulai terkena dampak dari inovasi dan memahami apa keuntungan dan fungsi inovasi dimaksud.

Pada tahap knowledge beberapa pendapat menyatakan pengambil keputusan dalam keadaan pasif sebelum sadar bahwa mereka membutuhkan inovasi. Oleh karena itu pada awal adopsi, knowledge pengambil keputusan pada posisi rendah.

Pada tahap persuasion sebesar 78,3\% anggota dalam kategori sedang s.d tinggi dalam memahami keuntungan budidaya 
kambing PE. Tahap persuasion terjadi ketika individu memiliki sikap terhadap inovasi. Sebagian besar anggota kelompok sudah mengetahui keuntungan secara ekonomi yang akan didapatkan dengan memelihara kambing PE dibandingkan memelihara kambing jenis lain.

Tabel 2. Persentase anggota kelompok ternak dalam proses pengambilan keputusan terhadap inovasi $(N=46)$

\begin{tabular}{lccc}
\hline $\begin{array}{c}\text { Proses } \\
\text { Pengambilan } \\
\text { Keputusan }\end{array}$ & $\begin{array}{c}\text { Menda } \\
\text { sari }\end{array}$ & $\begin{array}{c}\text { Mantep } \\
\text { Makaryo }\end{array}$ & Total \\
\hline \multicolumn{1}{c}{$(1)$} & $(2)$ & $(3)$ & $(4)$ \\
\hline Knowledge & & & \\
Tinggi & 20.0 & 14.3 & 17.4 \\
Sedang & 76.0 & 71.4 & 73.9 \\
Rendah & 4.0 & 14.3 & 8.7 \\
Persuasion & & & \\
Tinggi & 12.0 & 9.5 & 10.9 \\
Sedang & 76.0 & 57.1 & 67.4 \\
Rendah & 12.0 & 33.3 & 21.7 \\
Decision & & & \\
Tinggi & 28.0 & 4.8 & 17.4 \\
Sedang & 72.0 & 81.0 & 76.1 \\
Rendah & 0.0 & 14.3 & 6.5 \\
Implementation & & & \\
Tinggi & 36.0 & 23.8 & 30.4 \\
Sedang & 60.0 & 61.9 & 60.9 \\
Rendah & 4.0 & 14.3 & 8.7 \\
Confirmation & & & \\
Tinggi & 16.0 & 23.8 & 19.6 \\
Sedang & 84.0 & 61.9 & 73.9 \\
Rendah & 0.0 & 14.3 & 6.5 \\
\hline sunberi & & & \\
\hline
\end{tabular}

sumber: hasil survei, diolah

Sementara terkait dengan tingkat persuasi anggota kelompok Mantep Makaryo sebanyak33,3\% masih berkategori rendah, hal ini sesuai dengan indikator tingkat pendidikan anggota kelompok (86\% anggota setara dan tidak tamat SD) karena sikap ini menyangkut kemampuan pikir individu. Rogers (1983), menyatakan bahwa persuasion stage bersifat afektif, menyangkut perasaan individu. Afektif menurut kamus Besar Bahasa Indonesia adalah ranah yang terkait perasaan sementara kognitif berhubungan dengan pengetahuan.
Beberapa pakar mengatakan bahwa sikap afektif seseorang akan cepat menyesuaikan apabila mempunyai kemampuan kognitif yang memadai. Oleh karena itu pengambil keputusan yang berpendidikan cukup akan lebih cepat bersikap terhadap proses inovasi daripada yang berpendidikan rendah.

Pada tahap decision, 93,5 persen anggota kelompok dalam kategori sedang s.d tinggi untuk memilih mengadopsi budidaya kambing PE. Sebanyak 14,3 \% anggota kelompok Mantep Makaryo masih berkategori rendah merupakan anggota kelompok yang baru memutuskan adopsi pada tahun 2016. Secara umum mereka menerima adopsi, tetapi mereka tidak berani mengambil resiko. Selain karena keterbatasan modal untuk pengadaan bibit/indukan, mereka juga bersifat pasif, berharap mendapat hibah bibit/ indukan kambing PE dari kelompok.

Sampai dengan tahap ketiga, semua anggota kelompok telah menerima dan membuat keputusan untuk mengadopsi budidaya kambing PE. Adopsi adalah keputusan untuksecara penuh menggunakan/ menerima suatu inovasi sebagai tindakan yang terbaik (Rogers, 1983). Oleh karena itu tahap implementation dan confirmation, sebagai bagian akhir dari proses adopsi inovasi telah selesai pada tahap ini. Sebagaimana beberapa studi yang dilakukan, tahapan dalam adopsi inovasi tidak selalui mengikuti proses adopsi seperti yang diungkapkan Rogers, adopsi bisa dimulai dari decision apabila pada awal inovasi diperkenalkan kepada suatu sistem, sebagaian besar anggotanya sudah mengenal inovasi dimaksud

Adopsi inovasi kambing PE pada kelompok ternak Mendasari dan Mantep Makaryo dapat dikatakan tidak mengikuti proses adopsi Rogers, tetapi proses adopsi cenderung dimulai dari pengambilan keputusan sejak program ini digulirkan di masing-masing kelompok.

\section{Kategori adopter dalam adopsi inovasi}

Dalam proses adopsi inovasi, setiap individu dalam kelompok membutuhkan waktu dan kecepatan yang tidak selalu 
sama satu dengan yang lainnya. Waktu yang dibutuhkan setiap anggota kelompok untuk menerima adopsi juga berbeda-beda.

Tabel 3. Persentase Peternak Menurut Kategori Adopter

\begin{tabular}{lcccc}
\hline Kategori & $\begin{array}{c}\text { Jangka } \\
\text { Waktu }\end{array}$ & $\begin{array}{c}\text { Menda- } \\
\text { sari }\end{array}$ & $\begin{array}{c}\text { Mantep } \\
\text { Makaryo }\end{array}$ & Total \\
\hline (1) & $(2)$ & $(3)$ & $(4)$ & $(5)$ \\
\hline Cepat & & & & \\
Innovator & 0 tahun & 8.0 & 4.8 & 6.5 \\
E a r I y & $0-1$ tahun 76.0 & 66.7 & 71.7 \\
Majority & & & & \\
$\begin{array}{l}\text { Sedang } \\
\text { Late }\end{array}$ & & & \\
Majority & 2-4 tahun & 16.0 & 19.0 & 17.4 \\
Lambat & & & & \\
Laggard & $>4$ tahun 0.0 & 9.5 & 4.3 \\
\hline
\end{tabular}

sumber: hasil survey, diolah

Rogers (1983), telah membuat kategori adopter berdasarkan kurva normal dan membagi adopter menurut tingkat keinovatifannya menjadi 5 kategori. Kecepatan adopsi biasanya diukur dengan berapa lama jangka waktu yang diperlukan oleh sekian persen anggota masyarakat untuk mengadopsi inovasi

Keinovatifan dalam proses adopsi kambing PE terjadi cukup cepat di awal inovasi ini diperkenalkan kepada kelompok kemudian melambat pada akhir periode. Proses adopsi pada kelompok Mendasari selesai pada saat kategori late majority, dengan ketiadaan anggota kelompok pada kategori laggards. Sementara pada kelompok Mantep Makaryo masih menyisakan kategori laggards sebesar $9,5 \%$. Kurva yang terbentuk berupa kurva miring ke kiri ( nilai skewness $=-1,509$ ), bukan kurva normal sebagaimana yang disampaikan Rogers. Hal ini menunjukkan sebagian besar adopter tidak membutuhkan waktu lama untuk mengadopsi inovasi budidaya kambing PE. Sejalan dengan tahap knowledge dan persuasion yang sebagian besar pada kategori sedamg s.d tinggi, proses adopsi tidak sesuai tahapan adopsi inovasi yang selama ini di kemukakan Rogers

Akibat dari kemiringan kurva, kategori early adopter tidak dapat teridentifikasi secara jelas, karena pada tahap awal sebanyak 71,7 $\%$ anggota telah mengadopsi dalam kurun waktu 0 - 1 tahun, sehingga peneliti cenderung memasukkannya ke dalam kategori early majority.

Pada kelompok ternak Mendasari dan Mantep Makaryo, rentang waktu dari anggota mulai mengenal kambing PE hingga semua anggota kelompok menerima budidaya kambing PE adalah 0 - 6 tahun. Untuk itu peneliti membut kategori keinovatifan anggota yaitu 0-1 tahun (cepat), (2-4) tahun (sedang) dan lebih dari 4 tahun (lambat).

Karakteristik masing-masing kelompok adopter ditentukan berdasarkan kriteria karakteristik personal (petani) serta perilaku komunikasi dan hubungan sosial di lingkungannya sebagai suatu sistem sosial (Rangkuti, 2007). Oleh karena itu dari 3 (tiga) pendekatan dalam menentukan keinovatifan anggota kelompok dalam adopsi inovasi yaitu kapan mulai mengenal kambing $P E$, siapa yang paling awal membudidayakan kambing PE di dalam kelompok dan kapan anggota mulai memelihara kambing PE diperoleh informasi sebagai berikut:

1. Pada kelompok ternak Mendasari dan terdapat 2 (dua) aktor sebagai innovator yaitu aktor \#24 dan \#14, sementara pada kelompok Mantep Makaryo hanya 1 (satu) orang yaitu aktor \# 17.

2. Aktor \#24 pada kelompok ternak Mendasari sudah mengenal dan mulai budidaya kambing PE sejak tahun 2004. Sebagian anggota kelompok juga memastikan bahwa aktor \#24 adalah orang yang pertama kali memelihara kambing PE di kelompok ini. Sementara aktor \#14 telah mengenal kambing PE sejak tahun 2000, tetapi yang bersangkutan mulai membudidayakan kambing PE sejak tahun 2006. Kedua orang ini menjadi perintis berdirinya kelompok tani pada tahun 2008.

3. Aktor \#17 pada kelompok ternak Mantep Makaryo sudah mengenal dan memelihara kambing PE sejak tahun 1992. Hampir semua anggota kelompok 
$(95,2 \%)$ menyatakan bahwa aktor \#17 adalah orang pertama yang memelihara kambing PE hingga kelompok ini mulai mengadopsi budidaya ini pada tahun 2010.

Pada tahun ke-4 semua anggota kelompok ternak Mendasari sudah mengadopsi budidaya kambing $\mathrm{PE}$, sementara pada kelompok ternak Mantep Makaryo, terdeteksi kategori laggard sebanyak 9,5\%. Mereka baru mulai budidaya pada tahun 2016 sedangkan mereka telah bergabung dengan kelompok sejak 2010. Aktor pada kategori ini merupakan anggota kelompok yang tidak mau mengambil resiko, mereka mulai memelihara kambing PE setelah mendapat titipan (hibah) kambing PE dari kelompok. Beberapa aktor yang masuk kategori laggard bukan karena pengetahuan yang kurang memadai, tetapi lebih kepada adanya hambatan teknis ketika akan mulai menerapkan inovasi seperti permodalan. Hasil penelitian Farkhi (2012) menyatakan dari sisi pengetahuan, pada dasarnya responden sudah memahami, namun terkadang dalam penerapannya mengalami hambatan teknis seperti kondisi lahan yang tidak sesuai.

Gambar 1. Perbandingan grafik kategori adopter hasil penelitian dengan teori

Rogers 1983

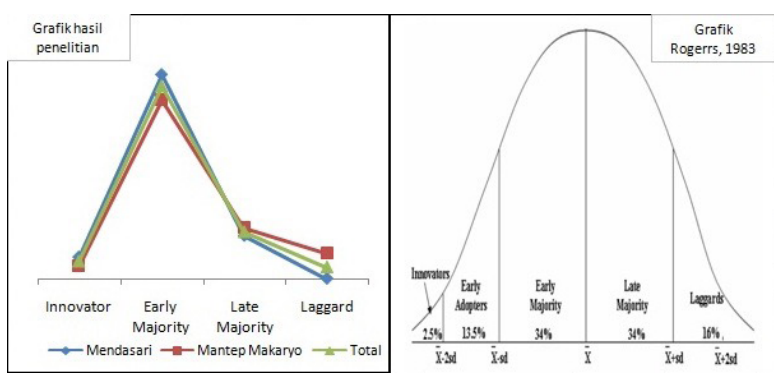

(sumber : hasil survey di olah dan Rogers, 1983)

Keinovatifan dalam proses adopsi kambing PE terjadi cukup cepat di awal inovasi ini diperkenalkan kepada kelompok kemudian melambat pada akhir periode. Proses adopsi pada kelompok Mendasari selesai pada saat kategori late majority.

Sementara pada kelompok Mantep Makaryo, pada tahap knowledge, menunjukkan sebagian besar anggota berpengetahuan sedang dan tinggi. Hanya $8,7 \%$ anggota yang berpengetahuan rendah. Anggota kelompok Mendasari yang berpengetahuan sedang dan tinggi sebesar $96 \%$, sementara pada kelompok Mantep Makaryo 85,7\%. Hal ini menyebabkan proses adopsi dapat berlangsung lebih cepat. Tercatat sebanyak $56 \%$ anggota kelompok ternak Mendasari, sudah mengenal kambing jenis ini sebelum mereka mendirikan kelompok ternak (2008), sementara pada kelompok ternak Mantep Makaryo hanya $28,6 \%$ anggota yang sudah mengenal kambing PE sebelum bergabung dengan kelompok. Banyaknya anggota yang sudah mengenal kambing PE sebelum bergabung dengan kelompok akan mempercepat proses adopsi dalam kelompok. Sehingga tahap pengambilan keputusan terhadap inovasi selanjutnya tidak dilalui sebagaimana yang Rogers kemukakan.

Pada tahap persuasion sebesar 78,3\% anggota dalam kategori sedang s.d tinggi dalam memahami keuntungan budidaya kambing PE. Tahap persuasion terjadi ketika individu memiliki sikap terhadap inovasi. Sebagian besar anggota kelompok sudah mengetahui keuntungan secara ekonomi yang akan didapatkan dengan memelihara kambing PE dibandingkan memelihara kambing jenis lain. Sementara terkait dengan tingkat persuasi anggota kelompok Mantep Makaryo sebanyak 33,3 $\%$ masih berkategori rendah, hal ini sesuai dengan indikator tingkat pendidikan anggota kelompok (86\% anggota setara dan tidak tamat SD) karena sikap ini menyangkut kemampuan pikir individu. Rogers (1983), menyatakan bahwa persuasion stage bersifat afektif, menyangkut perasaan individu. Afektif menurut kamus Besar Bahasa Indonesia adalah ranah yang terkait perasaan sementara kognitif berhubungan dengan pengetahuan. Beberapa pakarmengatakan bahwa sikap afektif seseorang akan cepat menyesuaikan apabila mempunyai kemampuan kognitif yang memadai. Oleh karena itu pengambil keputusan yang berpendidikan cukup akan lebih cepat bersikap terhadap proses inovasi daripada yang berpendidikan rendah. 
Pada tahap decision, 93,5 persen anggota kelompok dalam kategori sedang s.d tinggi untuk memilih mengadopsi budidaya kambing PE. Sebanyak 14,3 \% anggota kelompok Mantep Makaryo masih berkategori rendah merupakan anggota kelompok yang baru memutuskan adopsi pada tahun 2016. Secara umum mereka menerima adopsi, tetapi mereka tidak berani mengambil resiko. Selain karena keterbatasan modal untuk pengadaan bibit/ indukan, mereka juga bersifat pasif, berharap mendapat hibah bibit/indukan kambing PE dari kelompok. Sampai dengan tahap ketiga, semua anggota kelompok telah menerima dan membuat keputusan untuk mengadopsi budidaya kambing PE.

Adopsi adalah keputusan untuk secara penuh menggunakan/menerima suatu inovasi sebagai tindakan yang terbaik (Rogers, 1983). Oleh karena itu tahap implementation dan confirmation, sebagai bagian akhir dari proses adopsi inovasi telah selesai pada tahap ini. Sebagaimana beberapa studi yang dilakukan, tahapan dalam adopsi inovasi tidak selalui mengikuti proses adopsi seperti yang diungkapkan Rogers, adopsi bisa dimulai dari decision apabila pada awal inovasi diperkenalkan kepada suatu sistem, sebagaian besar anggotanya sudah mengenal inovasi dimaksud

Adopsi inovasi kambing PE pada kelompok ternak Mendasari dan Mantep Makaryo dapat dikatakan tidak mengikuti proses adopsi Rogers, tetapi proses adopsi cenderung dimulai dari pengambilan keputusan sejak program ini digulirkan di masing-masing kelompok. Pemimpin akan membawa keberlangsungan dan inovasi atau ide adopsi. Pemimpin yang efektif memiliki gaya kepemimpinan dan perilakunya yang menarik untuk memenuhi kebutuhan orang lain terutama para pengikut mereka.

\section{Pengaruh Variabel Sosial Ekonomi terhadap dan Adopsi Inovasi}

Beberapa penelitian telah menyatakan bahwa variabel sosial ekonomi berpengaruh terhadap masing-masing variabel dependen dan independen yang diteliti pada penelitian ini. Setiawan (1989) dalam Eriyanto (2014) dalam penelitiannya menyatakan bahwa warga dengan kelas ekonomi tinggi menjadi pusat bertanya dan berposisi sebagai pemuka pendapat dari program yang dilakukan sebuah sistem sosial, daripada warga dengan kelas ekonomi rendah. Oleh karena itu penelitian ini berusaha melihat apakah variabel kontrol berpengaruh terhadap hubungan kedua variabel utama.

Hipotesis yang diuji pada bagian ini sebagai berikut :

$\mathrm{H}_{0}=$ tidak ada pengaruh variabel sosial ekonomi terhadap adopsi inovasi.

$\mathrm{H}_{1}=$ ada pengaruh variabel sosial ekonomi adopsi inovasi.

Dalam penelitian ini variabel independen berupa variabel sosial ekonomi yang diduga berpengaruh terhadap adopsi inovasi budidaya kambing PE. Indikator sosial ekonomi tersebut antara lain: umur, pendidikan, kepemilikan barang berharga, lahan dan ternak serta perumahan.

Tabel 4. Hasil Uji Anova pada Regresi Sederhana untuk tiap-tiap model

\begin{tabular}{clccc}
\hline Model & $\begin{array}{c}\text { Dependen } \\
\text { variabel }\end{array}$ & $\mathrm{R}$ & Sig & $\begin{array}{c}\text { Kepu- } \\
\text { tusan }\end{array}$ \\
\hline 1 & $\begin{array}{l}\text { knowledge } \\
\text { (knw) }\end{array}$ & 0,752 & 0,000 & \\
2 & persuasion(per) & 0,730 & 0,000 & \\
3 & decision (dec) & 0,635 & 0,002 & $\mathrm{H}_{0}$ \\
4 & $\begin{array}{l}\text { implementation } \\
\text { (impl) }\end{array}$ & 0,656 & 0,001 & ditolak \\
5 & $\begin{array}{l}\text { confirmation } \\
\text { (conf) }\end{array}$ & 0,660 & 0,001 & \\
\hline
\end{tabular}

sumber: hasil survey, diolah

Analisis anova pada regresi sederhana dengan dependen variabel masing-masing tahapan dalam proses adopsi (knowledge, persuasion, decision, implementation dan confirmation) menghasilkan hasil uji yng signifikan atas 5 model yang terbentuk. Kelima model signifikan pada $\alpha=5 \%$, sehingga $\mathrm{H}_{0}$ ditolak. Dengan demikian secara empiris dapat dibuktikan bahwa faktor sosial ekonomi berpengaruh terhadap adopsi inovasi yang 
terjadi pada kedua kelompok. Hasil uji menunjukkan bahwa variabel pendidikan, kepemilikan barang berharga, lahan- ternak serta perumahan menunjukkan hasil yang signifikan terhadap proses adopsi inovasi budidaya kambing PE pada kedua kelompok ternak.

Peternak yang tergabung dalam kelompok ternak Mendasari dan Mantep Makaryo sebagian besar (sekitar 69,6\%) berada pada kisaran usia 39 - 60 tahun. Penduduk pada kategori ini merupakan kelompok penduduk usia produktif (BPS) dimana mereka berkepentingan untuk mampu memenuhi kebutuhan hidup untuk dirinya sendiri dan keluarganya. Oleh karena itu, mereka berkepentingan untuk bergabung dengan kelompok ternak, dengan harapan memperoleh peningkatan pendapatan dari aktivitas yang mereka ikuti di dalam kelompok, termasuk didalamnya apabila kelompok menawarkan inovasi. Salah satu manfaat keberadaan inovasi di dalam kelompok adalah memberikan sumber daya dan kekuatan baru untuk menciptakan kesejahteraan (Drucker,1985), sehingga dipastikan bergabungnya mereka dalam kelompok merupakan salah satu upaya dari anggota untuk mendapatkan perbaikan pendapatan bukan sekedar mengikuti perilaku sebagian anggota masyarakat yang lain.

Menurut Rangkuti (2007), penduduk pada usia produktif dikategorikan sebagai orang yang akan mampu mengelola usahanya secara optimal, sehingga keterlibatan mereka dalam jaringan komunikasi kelompok peternak akan lebih baik daripada penduduk pada usia tidak produktif. Selain itu, pada kelompok usia produktif, anggota kelompok ini secara umum akan memiliki loyalitas yang lebih baik dibandingkan kelompok tidak produktif, hal ini dibuktikan dengan sebagian besar merupakan anggota yang terlibat sejak kelompok ternak didirikan karena mereka sadar bahwa usaha yang dilakukan bukan semata-mata untuk dirinya, melainkan juga untuk kesejahteraan keluarga dan masyarakatnya

Dilihataspekpendidikan, kelompokternak
Mendasari relatif lebih baik daripada Mantep Makaryo. Anggota kelompok Mendasari yang berpendidikan SD ke bawah sebanyak $24 \%$ sementara pada kelompok Mantep Makaryo sebanyak 76,1\%. Anggota kelompok ternak Mendasari yang lulus SLTA ke atas sebanyak $64 \%$ sementara pada kelompok ternak Mantep Makaryo sebesar 9,5\% . Awais (2014) menyatakan pendidikan sebagai faktor yang paling berpengaruh dalam membedakan perilaku sosial dan perilaku demografi. Hal ini berpengaruh pada dinamisasi dalam kelompok ternak untuk berani mengambil resiko. Dengan modal pendidikan formal, petani akan memiliki pengetahuan tentang keuntungan menuju praktek pertanian yang lebih modern (Soekartawi, 1998) Sebelum beralih ke kambing $P E$, sebagian besar peternak telah mengusahakan beberapa jenis kambing lokal seperti kambing kacang. Pada saat akan mulai budidaya kambing $\mathrm{PE}$, mereka harus berani untuk menjual kambing yang mereka miliki sebagai modal membeli induk kambing PE yang harganya cukup tinggi. Petani dengan latar belakang pendidikan yang rendah cenderung takut mengambil resiko, sehingga terkesan lambat dan bertumpu pada pengurus kelompok.

Menurut Mardikanto dalam Yusnita (2010), bahwa didalam proses adopsi teknologi baru akan sangat di pengaruhi oleh tingkat pendidikan petani dan masyarakat perdesaan pada umumnya. Dengan rata-rata pendidikan yang relatif lebih tinggi, kelompok ternak Mendasari, terlihat lebih mandiri dan mampu secara swadaya mengelola budidaya kambing PE, sementara dengan keterbatasan pendidikan anggotanya, kelompok ternak Mantep Makaryo lebih bersifat sentralistik, bertumpu pada sosok ketua kelompok, di dalam aktifitasnya, sehingga meskipun telah mendapatkan beberapa penghargan, kelompok ini terkesan kurang dinamis.

Selain pendidikan, faktor latar belakang ekonomi keluarga juga menjadi penyebab apakah seseorang akan berani mengambil resiko dalam menerima sebuah inovasi. Hal ini karena keputusan inovasi didasarkan analisis perkiraan biaya dimana masalah terbesarnya adalah sebuah ketidakpastian (Rogers, 1995 
dalam Yusnita, 2010).

Untuk mengukur kondisi ekonomi setiap anggota, digunakan 3 pendekatan yaitu kepemilikan barang berharga, kepemilikan lahan/ternak dan keadaan perumahan. Van den Ban dan Hawkins (1999) mengemukakan bahwa mereka yang cepat mengadopsi sebuah inovasi dapat dicirikan memiliki pendapatan dan taraf hidup yang relatif tinggi. Akan tetapi untuk memperoleh data pendapatan dari petani/peternak cukup sulit, karena petani/peternak tidak memiliki pendapatan yang rutin diterima untuk kurun waktu tertentu. Hanya pada musim panen atau pada saat membutuhkan dana, para petani/peternak akan menjual hasil panen maupun ternaknya, oleh karena itu melihat potret taraf hidup yang dijalani pada saat pendataan menjadi pendekatan yang dipilih dalam penelitian.

Pada kelompok ternak Mendasari, sebagian besar keadaan ekonomi anggotanya pada kategori sedang dan tinggi, dari ketiga indikator yang diukur yang berkategori sedang dan tinggi diatas $84 \%$. Sementara pada kelompok Mantep Makaryo $20 \%$ anggota keadaan ekonominya masih berkategori rendah. Sesuai pendapat Hawkins diatas, keadaan ekonomi diyakini akan berpengaruh terhadap proses adopsi. Kekurangan dalam ekonomi rumah tangga akan berpengaruh terhadap seberapa cepat mengadopsi terkait dengan resiko yang harus diambil dalam proses ini. Sebagian besar proses adopsi yang terjadi pada kelompok Mantep Makaryo harus dilakukan dengan menjual hewan ternak yang sudah terlebih dahulu diusahakan seperti kambing lokal, domba sebagai modal membeli bibit kambing PE. Oleh karena itu adopsi bagi anggota kelompok berkategori ekonomi rendah sangat berat dan perlu waktu yang lama untuk dilakukan.

\section{KESIMPULAN}

Berdasarkan hasil penelitian dapat diambil beberapa kesimpulan sebagai berikut:

Adopsi inovasi kambing PE pada kelompok ternak Mendasari dan Mantep Makaryo dapat dikatakan tidak mengikuti proses adopsi yang dikemukakan Rogers, sebagian besar anggota memutuskan mengadopsi budidaya kambing PE sejak program ini digulirkan di masing-masing kelompok. Pada tahap ketiga, hampir semua anggota kelompok telah menerima dan membuat keputusan untuk mengadopsi budidaya kambing PE

Faktor sosial ekonomi secara meyakinkan berpengaruh proses adopsi inovasi budidaya kambing PE. Indikator sosial ekonomi yang diukur, meliputi: umur, pendidikan, kepemilikan barang berharga, kepemilikan lahan dan ternak serta perumahan, berpengaruh signifikan terhadap proses adopsi inovasi budidaya kambing PE pada kedua kelompok.

Kelompok ternak Mendasari terlihat lebih inovatif dan dinamis dalam pengembangan ide dari inovasi daripada kelompok ternak Mantep Makaryo. Meskipun kelompok ternak Mantep Makaryo mendapat pendampingan dari FKH UGM, tetapi tidak serta merta membuat kelompok ini lebih dinamis dalam penyebaran informasi maupun tingkat keinovatifan, karena penelitian ini membuktikan bahwa dengan latar belakang kondisi sosial ekonomi yang relatif lebih baik, kelompok ternak Mendasari mampu menerapkan ide inovasi dan penyebaran informasi yang lebih merata. Hal ini menunjukkan faktor sosial ekonomi lebih dominan dalam mempengaruhi tingkat keinovatifan daripada faktor pendampingan pihak luar terhadap kelompok.

\section{DAFTAR PUSTAKA}

Arikunto, S. 2007. Manajemen Penelitian, Jakarta: Rineka Cipta.

Brennon A. Wood et al. 2014. Agricultural Science in the Wild: A Social Network Analysis of 
Farmer Knowledge Exchange, Plos ONE Journal Vol.9.

Bungin, Burhan. 2004. Metodologi Penelitian Kuantitatif Komunikasi, Ekonomi dan Kebijakan Publik Serta Ilmu-ilmu Sosial Lainnya. Edisi Pertama, Surabaya: Kencana

Devito, J.A. 2011. Komunikasi Antar Manusia, Edisi Kelima. Hunter College of The City University of New York. Jakarta: Profesional Books.

Drucker, Peter. 1985, Innovation and Enterpreunnership Practice and Principle, Harper Bussines

Eriyanto. 2014. Analisis Jaringan Komunikasi Strategi Baru dalam Penelitian Ilmu Komunikasi dan Ilmu Sosial Lainnya, Jakarta: Prenamedia Group

Gustina, Anna. 2007. Jaringan Komunikasi dan peran Perempuan dalam mempertahankan budaya Rudat, Tesis. Sekolah Pasca Sarjana IPB.

Hadiyanto. 2009. Desain Pedekatan Komunikasi Partisipatif Dalam Pemberdayaan Peternak Domba Rakyat. Jurnal Media Peternakan, Vol. 32 No.2, hal 145-154.

Hanafi, Abdillah. 1987.Memasyarakatkan Ide-ide Baru disarikan dari karya Evveret Rogers dan Floyd Shoemaker. Surabaya: Usaha Nasional.

Indrizal, E. 2006. Memahami Konsep Perdesaan dan Tipologi Desa di Indonesia (http://fisip. unand.ac.id/media/rpkps/M3.pdf)

Jahi, A. 1993. Komunikasi Massa dan Pembangunan Pedesaan di Negara-negara Dunia Ketiga, Suatu Pengantar. Jakarta: Gramedia.

Littlejohn, Stephen and Foss. 2011. Theories of Human Communication, Illionis: Waveland Press:

Monge. R Peter, Noshir S. Contractor. 2003. Theories of Communication Networks, Oxford University Press.

Muhtadi, A.S. 2003. Metode Penelitian Dakwah. Bandung : Pustaka Setia

Musyafak.AdanTatang.MI,StrategiPercepatanAdopsidanDifusilnovasiPertanianMendukung Prima Tani, Jurnal Analisis Kebijakan Pertanian Vol. 3 No. 1, Maret 2005

Program Pascasarjana UNS, 2013. Panduan Penulisan Tesis.

Rogers, Everett M and D. Lawrence Kincaid. 1981, Communication Network: Toward a new Paradigm for Research. The Free Press memillan Publishing,Inc., Columbus, Ohio.

Rogers, Everett. 1983. Diffusion Of Innovation. The Free Press. New York.

Rangkuti, Parlaungan A. 2007. Jaringan Komunikasi Petani Dalam Adopsi Inovasi Teknologi Pertanian. Tesis, Sekolah Pasca Sarjana IPB.

Rohim, Syaiful. 2016. Teori Komunikasi: perspektif, ragam dan aplikasi, Jakarta: Rineka Cipta

Setiawan, Bambang \& Ashadi Siregar. 1983. Metode Analisis Jaringan Komunikasi. Yogyakarta: Unversitas Gajah Mada.

Slamet, Y. 1982. Logika Analisa Survai. Surakarta : Hapsara

-2013.Statistik untuk Penelitian Analisis Hubungan Dua Variabel. Surakarta: UNS Press

Sulistyawati, Asri. 2014. Analisis Jaringan Komunikasi dan Evaluasi Jaringan Kepemimpinan Dalam Gabungan Kelompok Tani. Tesis. Sekolah Pasca Sarjana IPB.

Sopiana. 2002. Hubungan Karakteristik Petani dan Jaringan Komunikasi dengan Perilaku Usahatani Tebu. Tesis. Bogor:Institut Pertanian Bogor. 
Sahin, Ismail. Detailed Review Of Rogers Difusion of Innovation Theory and Educational Technology Related Studies Based On Rogers Theory. The Turkish Online Journal of Educational Technologi-TOJET. Vol 5 Issue 2, April 2006

Sidik, MA. 2007. Difusi Inovasi Teknologi Pengelolaan Sampah Pada Masyarakat. Jurnal Teknologi Lingkungan Vol.8 No.3, September 2007

Su Han Woo, et al. 20134. Seaport Research: An Analysis of Research Collaboration using Social Network Analysis, Transport Reviews, 2013 Vol. 33, No. 4, 460-475

Stephen Ellingson, dkk. 2009. The Structure of Religious Environmentalism: Movement Organizations, Interorganizational Networks, and Collective Action. Journal For The Scientific Study Of Religion (2012) 51 (2): 266-285

Sujarweni, V. Wiratna. 2014. SPSS Untuk Penelitian, Yogyakarta: Pustaka Baru Press

Suprapto, Tommy, 2009. Pengantar Teori dan Manajemen Komunikasi, Yogyakarta: MedPress

Uwais M dan Nizamuddin Khan, 2014. Adoption of New Agricultural Technology: A case study of Buksa tribal farmer in Bijnor District, Western Uttar Pradesh, India. International Journal of Agriculture, Environment \& Biotechnology (2014)7 (2): 403-408

W.S. Winkel. 1997. Bimbingan dan Konseling di Institusi Pendidikan. Jakarta: Grasindo 